Deleuze and Queer Theory 


\section{Deleuze Connections}

'It is not the elements or the sets which define the multiplicity. What defines it is the AND, as something which has its place between the elements or between the sets. AND, AND, AND - stammering.'

Gilles Deleuze and Claire Parnet, Dialogues

\section{General Editor}

Ian Buchanan

Editorial Advisory Board

Keith Ansell-Pearson

Rosi Braidotti

Claire Colebrook

Tom Conley

Gregg Lambert

Adrian Parr

Paul Patton

Patricia Pisters

Titles Available in the Series

Ian Buchanan and Claire Colebrook (eds), Deleuze and Feminist Theory Ian Buchanan and John Marks (eds), Deleuze and Literature Mark Bonta and John Protevi (eds), Deleuze and Geophilosophy Ian Buchanan and Marcel Swiboda (eds), Deleuze and Music Ian Buchanan and Gregg Lambert (eds), Deleuze and Space Martin Fuglsang and Bent Meier Sørensen (eds), Deleuze and the Social Ian Buchanan and Adrian Parr (eds), Deleuze and the Contemporary World

Constantin V. Boundas (ed.), Deleuze and Philosophy

Ian Buchanan and Nicholas Thoburn (eds), Deleuze and Politics

Chrysanthi Nigianni and Merl Storr (eds), Deleuze and Queer Theory

Jeffrey A. Bell and Claire Colebrook (eds), Deleuze and History

Forthcoming Titles in the Series

Mark Poster and David Savat (eds), Deleuze and New Technology

Laura Cull (ed.), Deleuze and Performance

Ian Buchanan and Laura Guillaume (eds), Deleuze and the Body

Stephen Zepke and Simon O'Sullivan (eds), Deleuze and Contemporary Art

Paul Patton and Simone Bignall (eds), Deleuze and the Postcolonial 


\section{Deleuze and Queer Theory}

Edited by Chrysanthi Nigianni and Merl Storr

Edinburgh University Press 
(C) in this edition, Edinburgh University Press, 2009

(C) in the individual contributions is retained by the authors

Edinburgh University Press Ltd

22 George Square, Edinburgh

Typeset in 10.5/13 Sabon

by Servis Filmsetting Ltd, Stockport, Cheshire, and printed and bound in Great Britain by MPG Books Group

A CIP record for this book is available from the British Library

ISBN 9780748634040 (hardback)

ISBN 9780748634057 (paperback)

The right of the contributors

to be identified as authors of this work

has been asserted in accordance with

the Copyright, Designs and Patents Act 1988. 